Aprovado em: 13/08/2018

\title{
O ENTRETENIMENTO POLÍTICO EM SPIELBERG: IMAGEM E OLHAR NO CINEMA PÓS 11 DE SETEMIBRO
}

\section{THE POLITICAL ENTERTAINMENT IN SPIELBERG'S WORK: IMAGE AND GAZE IN POST-9/11 CINEMA}

\author{
Fabio Francener Luciano PINHEIRO ${ }^{1}$
}

\section{Resumo:}

Procuramos demonstrar uma conexão entre entretenimento - simbolizado pela produção de filmes nos estúdios de Hollywood - e política, a partir da análise de trechos do filme A Nova Lei (Minority Report 2002). O diretor Steven Spielberg - ele mesmo um ícone do cinema associado ao entretenimento - questiona o engano das imagens e o olhar como fonte de conhecimento. Trata-se de duas referências à midiatização dos atentados de 11 de setembro de 2001, na contramão do cinema engajado, naquele momento, no apoio à intervenção militar no Iraque. A noção de entretenimento político, com o horror de ver, é sustentada ainda em Guerra dos Mundos, de 2005.

Palavras-chave: Entretenimento, Política, Spielberg Imagem, Olhar.

\begin{abstract}
:
We try to demonstrate a connection between entertainment - symbolized by the production of films from Hollywood studios - and politics, from the analysis of scenes from the film Minority Report (2002). Filmmaker Steven Spielberg - an icon of the entertainment cinema-criticizes the deception of imagens and the gaze as a source of knowledge. These are references to mediatization of 9/11/2001 attacks, against cinema engaged that moment in supporting intervention military in Iraq. The idea of a political entertainment, as horror of seeing, is still supported by War of the Worlds, 2005.
\end{abstract}

Keywords: Entertainment, Politics, Spielberg, Image, Gaze.

1 Doutor pelo Programa de Pós-Graduação em Meios e Processos Audiovisuais Escola de Artes e Comunicações da Universidade de São Paulo (2018) com tese sobre o Cinema, melodrama e história. Professor Assistente da Graduação em Cinema da Faculdade de Artes do Paraná (FAP/UNESPAR). Email: falupin@gmail.com. 
Introdução

A história do mais conhecido centro produtor de cinema voltado para o entretenimento revela que, quando as imagens originadas no mundo histórico se tornam duras demais para serem digeridas pelo público, os estúdios de Hollywood chamam para si a responsabilidade de reestabelecer uma certa ordem imaginária, elaborar medos e angustias e ainda dar forma ao incompreensível ${ }^{2}$. Nos primeiros anos após a introdução do som sincronizado, os fantasmas da Depressão de 1929 foram exorcizados em filmes de monstros como Drácula e Frankenstein. Nos anos 1950, o medo da bomba nuclear gerou centenas de filmes B com monstros gigantes. A paranoia da invasão comunista pelos soviéticos resultou em produções sobre invasões alienígenas, que dominavam mentes e corpos.

O universo da experiência audiovisual é um negócio que movimenta bilhões, com grandes players competindo entre si e se fundindo - como no recente acordo entre FOX e Disney - ampliando assim a concentração deste setor. Gigantescas corporações de entretenimento decidem, controlam, produzem e divulgam o que vemos e ouvimos, em filmes, programas de televisão, séries, games, parques temáticos, discos e shows. $\mathrm{O}$ processo de concentração dos negócios do entretenimento - filmes exibidos no circuito são apenas uma de suas faces - começa nos anos 1980 e ganha impulso nas décadas seguintes (BORDWELL, THOMPSON, 2002).

\section{Spielberg: indústria e crítica}

É justamente nesta época que Steven Spielberg ganha visibilidade como o cineasta que simboliza o filme de entretenimento, com finais felizes e narrativas capazes de quebrar recordes de bilheteria. Tubarão (1977) lança a lógica do blockbuster, o filme que ocupa imenso número de salas e conta com divulgação em diversas mídias; Caçadores da Arca Perdida (Raiders of the Lost Ark, 1981) recupera o espírito dos antigos seriados de aventura com um herói que será retomado em outros três filmes nos anos seguintes; E.T. (1982) arrasta ainda mais multidões aos cinemas narrando uma das

\footnotetext{
${ }^{2}$ Não se trata de uma afirmação que possa ser aplicada exclusivamente as companhias produtoras localizadas em Los Angeles, pois há grandes centros produtores de filmes de apelo popular em outros países, como a Índia, Nigéria, Coréia do Sul. Tomamos Hollywood como um modelo devido à visibilidade global de suas produções.
} 
obsessões do diretor - a infância solitária em um lar sem a presença paterna. A impressão é que Spielberg é um midas do cinema, pois tudo que toca se transforma em bilheterias estratosféricas.

Sintetizando em números: Tubarão - US\$ 1,2 bilhão, ajustados pela inflação, apenas no mercado doméstico: Caçadores da Arca Perdida - US\$ 678,4 milhões; E.T. - US\$ 1,1 bilhão ${ }^{3}$. Em abril de 2018, Spielberg torna-se o primeiro diretor da história a atingir uma bilheteria acima de US\$ 10 bilhões, somando todos os 32 filmes que dirigiu ${ }^{4}$. Além da direção, ele também atua como produtor executivo e está por trás de alguns dos filmes que costumam atrair multidões aos cinemas: Poltergeist (1982), Gremlins (1984), Goonies (1985), De Volta para o Futuro (Back to the Future,1985), Homens de Preto (1997), Transformers (2007), além de franquias, documentários e séries para a televisão. Na lista dos bilionários da Forbes, ele ocupa a posição de número 215 nos Estados Unidos e 629 no mundo, com uma fortuna pessoal de US\$ 3,6 bilhões ${ }^{5}$.

Com tamanho poder e influência no universo do entretenimento, ao ponto de ser privilegiado com orçamentos generosos, seria de se esperar que sua obra fosse o reflexo destes números, ou seja, nada mais que filmes de massa formatados para divertir e serem consumidos em grande escala. A crítica nunca perdoou este aspecto comercial dos filmes do cineasta, que foi acusado, ao lado de George Lucas, de ter enterrado o momento de inovações da Nova Hollywood, com seus filmes-evento, que empurram para longe as obras mais pessoais e autorais e no circuito global ainda sufocam as cinematografias nacionais. (FRIEDMAN, 2006, MC BRIDE, 2011).

Tal ideia não se sustenta com a análise mais atenta dos filmes do cineasta. Um êxito comercial não pode ser, em si, critério de avaliação, assim como filmes de pouca ou rara circulação por si não são todos obrigatoriamente obras de grande valor artístico e crítico. A crítica e o universo acadêmico torcem o nariz para Spielberg e o associam ao entretenimento despolitizado, o que não se confirma.

\footnotetext{
3 Disponível em: http://www.businessinsider.com/all-steven-spielberg-movies-ranked-by-box-officegross-2018-3\#2-et-the-extra-terrestrial-1982-29. Acesso em 30/05/2018.

4 Disponível em: https://www.hollywoodreporter.com/news/steven-spielberg-s-top-10-803126 .Acesso em 30/05/2018.

${ }^{5}$ Disponível em: https:/www.forbes.com/profile/steven-spielberg/ Acesso em 30/05/2018.
} 
Em seus filmes, a infância, por exemplo, é um mundo difícil e solitário - como em E.T(1982), Contatos Imediatos do Terceiro Grau (1977), Império do Sol (1987), A.I (2001). Temas complexos e polêmicos não foram ignorados pelo cineasta, como a escravidão e os Direitos Civis - A Cor Púrpura (1985), Amistad(1997) e Lincoln(2012) - Holocausto - A Lista de Schindler (1993) e Munique (2005) - Segunda Guerra Mundial - O Resgate do Soldado Ryan, (1998) - Guerra Fria - Ponte dos Espiões (2015), a experiência virtual se impondo sobre o real - Jogador Número 1 (2018), a busca pela verdade na era das fake news - The Post (2018).

$\mathrm{O}$ cineasta se equilibra sobre filmes que circulam como aventuras, fantasias ou ficções científicas, considerados como entretenimento, e projetos mais pessoais, como dramas, biografias e filmes históricos, seus "filmes sérios". Esta divisão não se justifica, pois, até em seus filmes mais amenos pós 11 de setembro, o cineasta abordou o trauma nacional e o clima político repressivo do período Bush-Cheney (MC BRIDE, 2011). Em sua filmografia há uma espécie de bipolaridade, que o leva a realizar simultaneamente, no ano de 1993, uma fantasia com dinossauros digitais em Jurassic Park (1993) e a recriar o Holocausto em A Lista de Schindler. Em 2018, os lançamentos simultâneos de The Post e da ficção futurista Jogador Número 1 confirmam este equilíbrio. Perguntado sobre os dois tipos de filme que costuma dirigir, ele se justifica:

Preciso fazer todos eles. Inclusive os que só podem ser avaliados como puro entretenimento escapista. Sinto a ânsia de entreter, e também de chamar a atenção sobre temas relevantes para que os jovens possam aprender com eles. Às vezes faço filmes porque sei que o público vai gostar deles, porque são uma aventura, com muitos efeitos especiais e grandes personagens, e sei que os espectadores vão gritar e rir e ficar loucos. Fiz Ready Player One por esse motivo. Mas não teria escolhido se não tivesse essa mensagem tão relevante sobre as decisões que temos de tomar hoje diante dessa alternativa: comprometer-se com os assuntos sociais ou perder-se em um mundo de realidade virtual ${ }^{6}$.

Minority Report encaixa-se neste perfil. Produzindo dentro do studio system, o mesmo que alimenta o patriotismo pós 11 de Setembro e as campanhas militares dos Estados Unidos, o filme também antecipa o clima de ataques aos Direitos Civis do governo Bush. Mixando apelo emocional e visual típicos do cinema de massa, com

\footnotetext{
${ }^{6}$ Disponível em https://brasil.elpais.com/brasil/2018/03/19/eps/1521458978_727072.html. Acesso em 20/05/2018.
} 
crítica ao papel da imagem na sociedade contemporânea e sua relação com o olhar, o cineasta constrói um sutil equilíbrio entre o registro do entretenimento e o político.

O Spielberg de Minority é diferente daquele de Tubarão e dos filmes de Indiana Jones. Após A Lista de Schindler, o diretor foi tornando seus filmes mais críticos, revisitando o passado dos Estados Unidos, elaborando dramas que debatem processos políticos. Suas imagens se tornaram mais violentas e mais explícitas. Ele não abandona em momento algum o terreno do entretenimento - cujos segredos conhece como poucos - mas vem se permitindo tirar proveito de sua posição privilegiada na indústria para fazer circular temas complexos e polêmicos. Spielberg vem caminhando rumo a um entretenimento mais politizado. Minority, mesmo tendo sido filmado de março a julho de 2001 - dois meses antes dos ataques - comprova este perfil ${ }^{7}$.

Os atentados de 11 de setembro e sua intensa miditiazação tiveram um impacto profundo naquela sociedade e em especial na indústria de entretenimento - neste caso, os estúdios de Hollywood. Os ataques suicidas simultâneos inclusive reavivaram a atmosfera angustiante que as imagens - desta vez ao vivo - haviam proporcionado 38 anos atrás com o assassinato do presidente John Kennedy em Dallas ${ }^{8}$. Se em 1963 a morte de Kennedy foi vista em alguns segundos quando o Zapruder film foi exibido nas emissoras de televisão, em 2001 o assassinato em massa de tripulantes, frequentadores das torres do edifício, bombeiros e policiais, foi transmitido ao vivo pelas redes de televisão americanas - em especial a CNN - e em outros países.

O choque inicial do público americano com os atentados fez com que o país ficasse sentado diante da televisão tentando encontrar algum sentido para as imagens que eram repetidas à exaustão, a tal ponto que para muitos a impressão era mais de um

\footnotetext{
${ }^{7} \mathrm{Na}$ manhã daquele dia, quatro aviões foram sequestrados: um foi jogado contra o Pentágono, em Arlington, na Virgínia, outro caiu na Pensilvânia após um conflito entre os sequestradores e os passageiros e as duas outras duas aeronaves foram jogadas contra o World Trade Center, em Nova York.

${ }^{8}$ Com uma câmera Bell \& Howell de $8 \mathrm{~mm}$, sem som, o cinegrafista amador Abraham Zapruder efetuou um curto registro do tiro de Lee Osvald destruindo a cabeça de Kennedy e o gesto desesperado da primeira-dama Jacqueline Kennedy tentando recuperar pedaços da massa encefálica espalhados pelo capô da limusine presidencial. O registro despertou a sociedade para um horror que só se imaginava possível na ficção. O filme foi revisto, ampliado, estudado fotograma a fotograma, gerou inúmeras teorias da conspiração e foi repetido como um pesadelo verdadeiro - pela primeira vez na história se registrava o assassinato de um presidente. O crítico francês Jean-Baptiste Thoret defende a ideia de que o Zapruder film e os debates que ele gerou são a matriz de uma ruptura que resultou em um cinema mais crítico, político, ousado e inovador ao final dos anos 1960 e começo dos anos 1970 (BAECQUE, 2012).
} 
disaster movie de verão do que eventos ocorrendo em tempo real (EDGERTON, HART, HASSENCAHL, 2007). O 11 de setembro, além de redefinir toda a cultura popular, evidenciou na década seguinte aos ataques um conceito de identidade nacional em processo de construção e de desconstrução em diversos filmes (WESTWELL, 2014).

O fato é que os atentados causaram um terremoto nos estúdios. Westwell cita um encontro, em outubro de 2001, de 40 executivos de estúdios de Hollywood, com assessores do presidente Bush na Casa Branca. Ao final da discussão de duas horas, Leslie Monvies, presidente da CBS, teria dito aos membros do governo: "Digam o que fazer. Nós não pilotamos aviões, mas temos habilidades que podem ser usadas aqui" (2014, p. 19). Em outro encontro em novembro, executivos de estúdios e de redes de $\mathrm{TV}$, representantes de sindicatos e proprietários de cadeias de salas exibidoras discutiram como Hollywood poderia ajudar o esforço de guerra. Agentes governamentais recomendaram que filmes e programas de televisão deveriam destacar o direcionamento da guerra seria contra o terrorismo e não contra o Islã, incentivar o serviço miliar e o apoio da população às tropas.

Nos lançamentos após os atentados, a primeira medida dos estúdios foi eliminar qualquer referência ao 11 de setembro. As torres gêmeas foram removidas de filmes como Homens de Preto II (2002) e do material promocional de Homem Aranha (2002). Lançamentos de 2002 como Fomos Heróis (We Were Soldiers, Randall Wallace, estreia em março), sobre a Batalha de La Drang, no Vietnã, em 1965, Falcão Negro em Perigo (Black Hawk Down, Ridley Scott, janeiro); sobre uma operação de rangers na Somália em 1993; Códigos de Guerra (Windtalkers, John Woo, junho), sobre a criação de um código secreto baseada na língua dos navajos e utilizado pelas tropas americanas nas operações do Pacífico em 1944, apresentam em comum os Estados Unidos como vítimas e a intervenção militar como uma necessidade moral.

Este ciclo de filmes, que mostra a guerra moderna como um imperativo moral em defesa dos direitos humanos e uma resposta a ataques não provocados se alinha perfeitamente (...) com a ideologia dominante da resposta ao 11 de setembro: um apelo nacionalista às armas. (WESTWELL, 2014, p. 22). 
Construções da identidade nacional por meio de filmes e uma patriótica defesa das campanhas nos Afeganistão e no Iraque foram princípios abraçados pelos estúdios como resposta aos ataques. "Filmes que desafiaram ou questionaram esta realidade foram empurrados para as margens", lembra o Westwell ${ }^{9}$.

Em Minority Report Spielberg não trata de conflitos militares como os outros títulos de 2002, mas de uma sociedade em que impera a hipervigilância, obtida por meio do medo da população diante das altas taxas de criminalidade. O cineasta ataca a crença cega na imagem e questiona o papel do olhar na organização de um sentido para a experiência humana. O trauma das imagens dos aviões chocando-se contra as torres e o impacto destas imagens sobre o olhar do público são reelaborados neste filme. As duas obsessões da sociedade americana naquele momento, a imagem e o olhar, são exploradas em um enredo que lida com os códigos visuais e narrativos da sci-fi e da ficção policial.

O filme se afasta do esforço governamental, dos estúdios e das emissoras de televisão para legitimar a intervenção militar no Iraque. Em 2002, o governo Bush anunciou uma política de ataques preventivos a países considerados hostis à segurança do país. A Doutrina Bush, defendida em discursos e documentos governamentais, sustentava que os Estados Unidos poderiam atacar preventivamente qualquer nação considerada inimiga ou seus apoiadores - o que resultou na segunda invasão do Iraque em 2003. A mudança do ambiente político durante a filmagem tornou o filme mais crítico.

"A antecipação ficcional de prevenção ao crime foi um estranho reflexo da antecipação e invasões reais" (WASSER, 2010, p. 186). Assim como no filme, o Governo, em nome da segurança nacional, atropela conquistas dos Direitos Civis, como a privacidade, por meio de tecnologias de intensa e permanente vigilância das atividades de seus cidadãos. Como no filme, a população é levada a crer que é positivo abrir mão

\footnotetext{
${ }^{9}$ Além da obra de Westell (Parallel lines - Post /11 American Cinema), o reflexo dos atentados no cinema de massa foi analisado em outros livros, como as coletâneas editadas por Wheeler Dixon (Film and Television After 9/11, 2004), Aviva Briefel e Sam Miller (World After 9/11: World of Fear, Cinema of Terror, 2012), Terrence McSweeney (American Cinema in the Shadow of 9/11, 2016) e as obras de John Markert (Post 9/11 Cinema - Trough a Lens Darkly, 2011), Kevin Wetmore Jr (Post 9/11 Horror in American Cinema, 2012) e Terence McSweeney (The War on Terror in American Film: 9/11 Frames per Second, 2016).
} 
de um pouco de sua liberdade em troca de paz. "Eu estou disposto a dar um pouco de minhas liberdades pessoais para evitar que o 11 de setembro não se repita. Mas a pergunta é: qual o limite? Quanta liberdade estamos dispostos a dar? O filme é sobre isso", declarou o cineasta (MC BRIDE, 2011, p. 491).

\section{Imagens e olhar em Minority Report}

A análise que apresentamos é motivada por aquele momento histórico e político após os atentados de 2001 e pela resposta cinematográfica imaginada pela cineasta a este quadro. Uma elaboração que, como vamos expor, questiona o papel das imagens e do olhar. Minority Report se passa em 2054, em Washington, deslocando-se do conto original de Philip Dick, situado em Nova York, ampliando assim a dimensão política do filme. A criminalidade, que atingiu índices alarmantes, foi abolida graças ao programa Pre Crime, um projeto privado que utiliza a projeção de imagens da mente de três jovens videntes para antecipar delitos. A partir da organização das imagens, que chegam em fragmentos, os policiais do Pre Crime conseguem se antecipar aos criminosos e prendê-los momentos antes de cometer um crime.

Uma das videntes, Agatha, tem uma visão de um assassinato, o que intriga o chefe do Pre Crime, John Anderton, um viciado na droga neuroin e que não consegue superar o desaparecimento do filho. Anderton - assim como Spielberg - desconfia da autenticidade destas imagens e passa a investigar estas visões e descobre que ele mesmo cometerá um crime. De agente da lei ele se torna um foragido, tendo que se submeter a uma cirurgia para mudar seus olhos e não ser identificado. Após sequestrar a vidente, ele realmente acaba matando o homem que apareceu na visão e que seria o assassino de seu filho. Porém descobre que foi uma cilada para incriminá-lo da imagem da mente de Agatha, que revelará um assassinato cometido pelo presidente da Pre Crime, Lamar. Já neste breve sinopse percebemos a referência à imagem que encobre a verdade e ao olhar que não dá conta de registrar com precisão o que está diante de si.

O filme inicia com fragmentos breves de imagens imprecisas e desfocadas de um casal fazendo sexo em um quarto, um homem de terno com uma tesoura nas mãos (figura 1), flashes de facadas, sangue, um close-up de olhos e uma máscara de papel com os olhos recortados. 


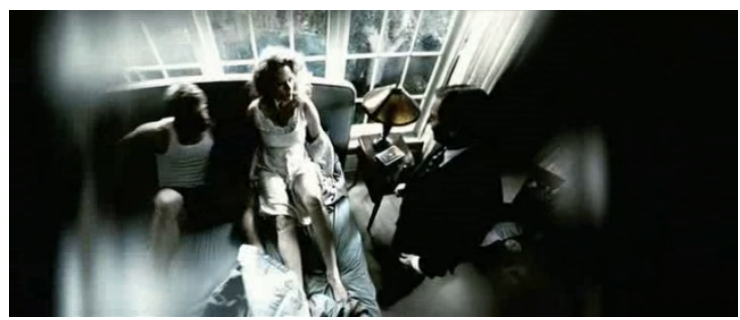

(figura 1$)^{10}$

Algumas das imagens movem-se em sentido contrário, em direção ao passado, até que vemos o close-up do olho da precog Agatha (2) ${ }^{11}$.

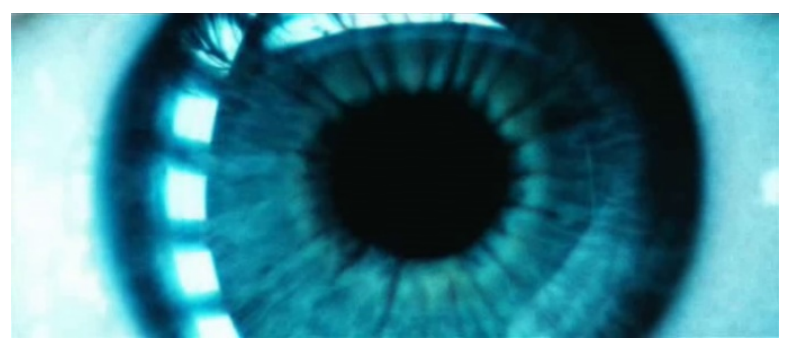

(figura 2)

Ela e os gêmeos Arthur e Dashiel ${ }^{12}$ são jovens mantidos sob sedativos em um uma piscina, com eletrodos conectados as suas cabeças para captar imagens produzidas por seus cérebros. São prisioneiros ou servidores do Estado que os escraviza e os mantém como máquinas para utilizar seus dons de vidência na prevenção de crimes.

Em seguida, duas esferas de madeira recebem a gravação dos nomes da vítima e do criminoso de um assassinato prestes a acontecer. De forma telegráfica e direta, ainda que ambígua devido à natureza das imagens, que farão sentido adiante, somos introduzidos ao eixo que sustenta o filme. O primeiro deles é o da imagem e sua natureza enganosa, subjetiva e fugidia. O outro trata do olhar, reforçado pelos planos próximos dos olhos e da máscara com orifícios, uma referência à dificuldade, impossibilidade e recusa de visualizar uma imagem com clareza - o que será

\footnotetext{
${ }^{10}$ Crédito dos frames: DVD FOX Filmes, 2003, 148'.

11 Referência à conhecida escritora britânica de romances policiais, Agatha Christie, uma das mais publicadas, traduzidas e lidas de toda a história da Literatura.

${ }^{12}$ Referência a dois conhecidos escritores de ficção policial, o britânico Arthur Conan Doyle, criador do personagem Sherlock Holmes, e o americano Dashiel Hammet, criador do detetive Sam Spade e inspiração para o gênero noir nos anos 1940 e 1950.
} 
confirmado na sequência, quando o homem de terno se posiciona do lado externo da casa e vê o amante da esposa entrando em sua casa.

As imagens desconexas do início são manipuladas visualizadas em uma tela transparente - menção clara ao cinema - por meio de luvas com sensores (3), pelo policial John Anderton (Tom Cruise) chefe do Pre Crime.

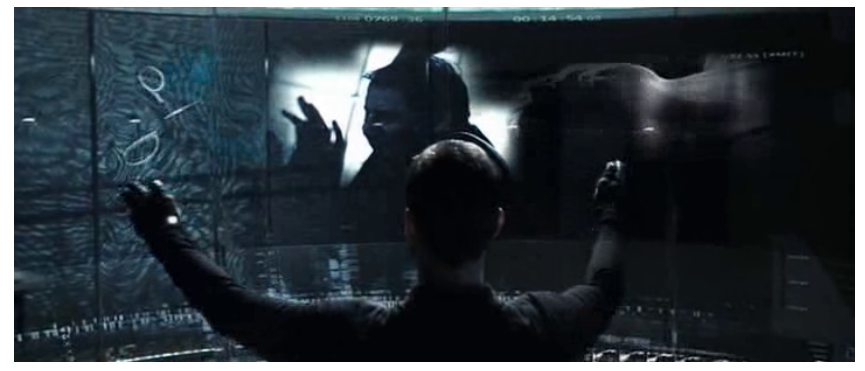

(figura 3)

Do outro lado da tela estão um juiz e uma promotora, encarregados de assistir às imagens e de validar a ação preventiva do crime. Na casa onde ocorrerá o crime previsto, uma mulher que recorta os olhos da máscara mostrada rapidamente antes (4). É a face do presidente Abraham Lincoln, o que se confirma quando ela diz "Há 87 anos atrás...".

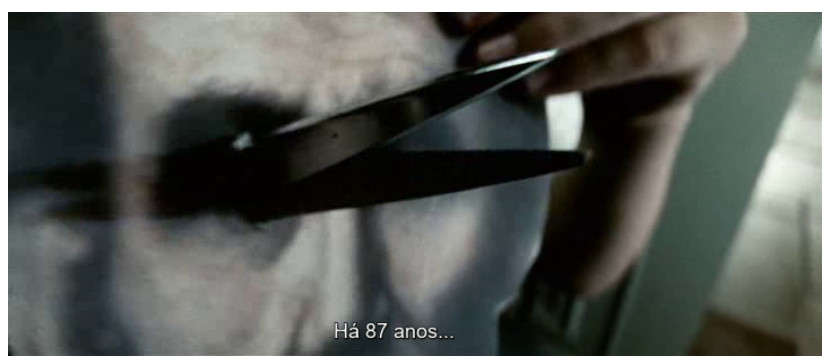

(figura 4)

É o início do pronunciamento mais popular de Lincoln, o discurso de Gettysburg $^{13}$. Em Minority Report, a breve presença ao discurso - em um trabalho escolar no qual a mãe reforça as palavras de Lincoln ao filho a cozinha da casa - pode

\footnotetext{
${ }^{13}$ Proferido em novembro de 1863, em Gettysburg, na Pennsylvania, no cemitério dedicado aos mortos da batalha que ocorreu entre o exército do Norte e os Confederados, com a vitória das tropas da União, resultando no embate com o maior número de vítimas de ambos os lados até aquele momento da Guerra Civil entre Norte e Sul. O discurso é encerrado com as seguintes palavras: "Que todos nós aqui presentes solenemente admitamos que esses homens não morreram em vão, que esta Nação, com a graça de Deus, renasça na liberdade, e que o governo do povo, pelo povo e para o povo jamais desapareça da face da Terra". Disponível em http://www.abrahamlincolnonline.org/lincoln/speeches/gettysburg.htm. Aceso em 02/06/2918.
} 
ser vista como uma lembrança das noções de igualdade e liberdade contidas no pronunciamento original ${ }^{14}$.

Pois com o programa Pre Crime e as visões dos precogs são justamente a liberdade e a privacidade que são deixadas de lado em prol da segurança, e a igualdade, como demonstra final do filme, não passa de uma ilusão, pois as visões podem ser manipuladas para proteger alguns e incriminar inocentes - o retorno ao engano da imagem. Os olhos de Lincoln são retirados da imagem como se o próprio presidente fosse poupado de ver a supressão desta liberdade e desta igualdade ${ }^{15}$.

O policial Anderton organiza as imagens da tela até conseguir identificar o futuro criminoso. A busca de uma informação inserida em uma imagem, mas que precisa ser ampliada e verificada com maior nitidez, faz uma clara referência a dois filmes: Blow Up e Blade Runner ${ }^{16}$. Anderton e um grupo de policias partem em veículos voadores que passam diante do Obelisco e da Casa Branca, em direção à casa onde o marido está sentado no chão, ao lado da cama em que sua esposa e o amante se beijam. No instante em que o marido levanta o braço com uma tesoura para ferir a mulher, Anderton entra pela janela e o segura. O marido é dominado pelos policiais e detido pela acusação de "crime futuro". No local chamado de Templo, no interior do Pre Crime, Samanta revê as imagens do crime, que são apagadas.

\footnotetext{
${ }^{14}$ Spielberg, admirador confesso de Lincoln, havia citado o político em o Resgate do Soldado Ryan (Saving Private Ryan, 1998), quando o general George Marshal lê para seus subordinados uma carta atribuída a Lincoln como incentivo para que o último Ryan vivo seja resgatado no norte da França após o desembarque das tropas americanas em 1944. Em 2012 Spielberg dirige Lincoln, em que Daniel Day Lewis interpreta o presidente envolvido com articulações políticas para a provação da $13^{\mathrm{a}}$ emenda dedicada à libertação dos escravos.

${ }^{15}$ Além destas associações, podemos trazer para a leitura o plano de Um Cão Andaluz, de Bunuel e Dali (Um Chien Andalou,1929) no qual um homem, em um noite de lua cheia, corta o globo ocular de uma mulher - uma imagem de impacto, que serve como chamado para um olhar renovado, ideal caro às vanguardas dos anos 1920 e em especial ao Surrealismo, o qual o filme se filia. A intenção destas correntes experimentais era libertar o público de sua cegueira, fazendo-o ver o mundo através das imagens desconexas dos sonhos. Não à toa, as primeiras imagens do filme assemelham-se ao fluxo ilógico dos sonhos e a mulher que ensaia o discurso de Gettysburg com a criança diz ao marido: "Você fica cego sem óculos".

${ }^{16}$ Blow up (Depois Daquele Beijo, 1967) do italiano Michelangelo Antonioni, trata de um fotógrafo que, ao revelar fotos tiradas em um parque, identifica, por acaso, um assassinato. Tanto Antonioni quanto Spielberg, em diferentes momentos históricos e em distintas propostas estéticas, refletem sobre a presença da imagem na sociedade moderna e seu potencial (ou perigo) de revelação e ilusão. Já a referência a Blade Runner (1982), de Ridley Scott, está no trecho em que o detetive Deckard (Harrison Ford) ordena a um computador, com comandos de voz, que o equipamento amplie e identifique minúsculos detalhes de uma fotografia. No caso de Scott, a cena sintetiza o próprio enredo do filme, que trata de humanos e suas cópias perfeitas, os replicantes.
} 
A referência ao olhar é reiterada em outros momentos do filme. Anderton compra neuroin, uma droga para lucidez ampliada, de um homem que usa óculos escuros e o reconhece pela voz. Ao desejar bons sonhos ao policial, o homem tira seus óculos e no lugar dos olhos nas órbitas existem dois grandes buracos (5). Ironicamente, o vendedor diz: "Em terra de cego quem tem um olho é rei” para tranquilizar o policial sobre o sigilo de sua identidade ao comprar a droga.

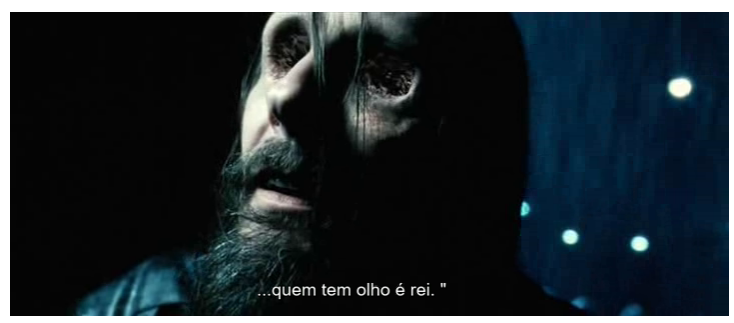

(figura 5)

Em casa, Anderton interage com uma imagem tridimensional do seu filho desaparecido (6), inala o neuroin e dorme. A imagem é projetada diante dele a partir da inserção de um cartão transparente em um computador.

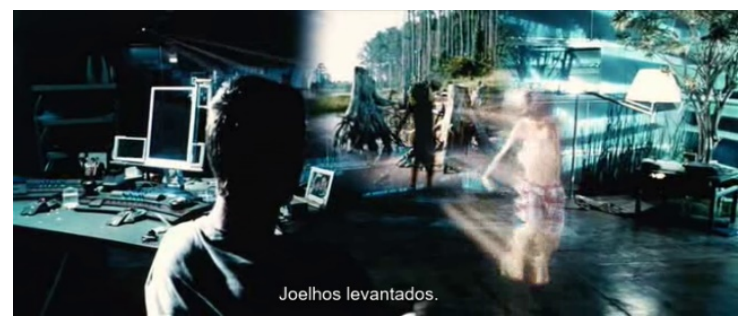

(figura 6)

Mas que uma referência à realidade virtual, popularizada sobretudo em games que inserem, por meio de óculos especiais, o jogador no ambiente do entretenimento, o trecho também sintetiza a nossa relação com a experiência prática no mundo contemporâneo. Como o policial narcotizado, estamos cercados de simulações do mundo, de representações, seja na ficção audiovisual, nas redes sociais, nos dispositivos de comunicação que colocam todos disponíveis a todos todo o tempo.

Nos relacionamos mais com imagens do que com a realidade. É possível também trazer para o trecho o pensamento do crítico francês André Bazin ${ }^{17}$ em que ele aborda a foto - e por extensão o cinema - como a vitória do ser humano sobre a morte, uma vez que a imagem é, para o crítico, testemunha da existência do ser a que se refere.

\footnotetext{
17 “Ontologia da Imagem Fotográfica”. O que é o cinema (2014).
} 
Se fotos em túmulos nos recordam dos familiares que partiram e eternizam suas ausências transformando-as em presença na representação, imagens reais tridimensionais e interativas de momentos passados como as vistas por Anderton com seu filho estendem os limites da representação de forma um tanto assustadora, ao possibilitar a simulação de uma interação com um morto.

Após ser perseguido pelos próprios colegas, Anderton precisa voltar ao Tempo, sequestrar a vidente e impedir que a visão dela sobre o crime cometido por ele se transforme em realidade. Mas para isso precisa ter seus olhos removidos, pois nesta sociedade livre da criminalidade o preço pago é a vigilância onipresente, por meio de câmeras com sensores que fazem a leitura das córneas de todo indivíduo que ocupa algum espaço público.

No metrô, os olhos dos passageiros são escaneados, eles podem ser rapidamente localizados rapidamente e ainda são submetidos a anúncios personalizados de bebidas, joias, viagens (figura 7) e outros itens e consumo.

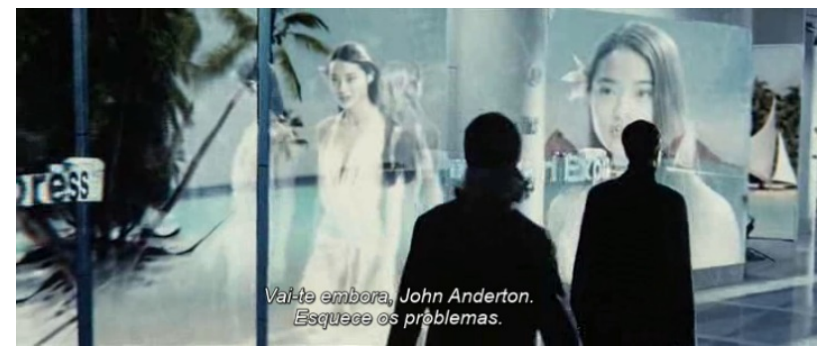

(figura 7)

Anderton procura o médico Solomon Eddie, que ele mesmo prendeu anos atrás por atear fogo em seus pacientes. O apartamento onde será feita a cirurgia é pequeno e sujo. Em uma das paredes é projetado um trecho do filme $A$ Casa de Bambu (The House of Bambu, 1955), de Samuel Fuller. Solomon aplica uma anestesia em Anderton, que é levado até a poltrona por sua assistente, Greta Van Eyck ${ }^{18}$.

$\mathrm{O}$ médico e a assistente falam em sueco enquanto Solomon encaixa uma armação com pinças e garras em volta da cabeça de Anderton, ajustando o equipamento

\footnotetext{
${ }^{18}$ Referência ao pintor flamengo Jan Van Eyck, que em 1434 criou o Retrato do casal Arnolfini. A pintura foi objeto de debates e análises em torno de seu simbolismo, mas o detalhe que mais chama atenção é justamente a presença de um espelho circular entre o casal retratado. No interior da imagem refletida no espelho o pintor inseriu a si mesmo e ao celebrante do casamento, com o casal de costas - um jogo repleto de detalhes com o olhar.
} 
- que parece um instrumento de tortura - em torno dos olhos do policial. O mecanismo é fixado nos globos oculares de Anderton, em uma referência a Laranja Mecânica (8). ${ }^{19}$. Solomon diz a Anderton: "Greta só tem olhos para você" (9), apontando a assistente, que segura um saco plástico com dois olhos que serão implantados no policial. $\mathrm{O}$ médico toca na tela de um computador e as garras do equipamento se movem em direção ao rosto de Anderton

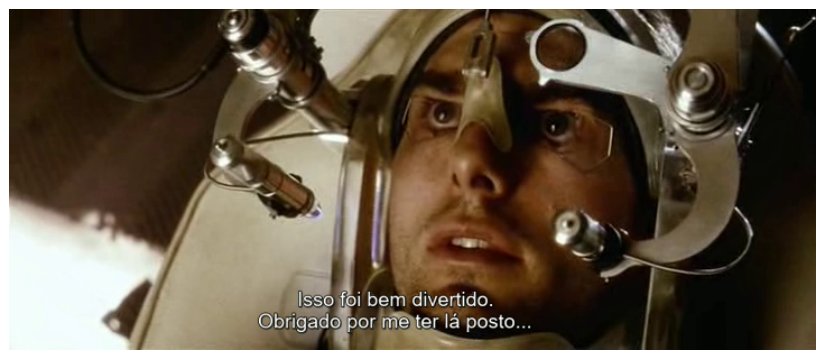

(figura 8)

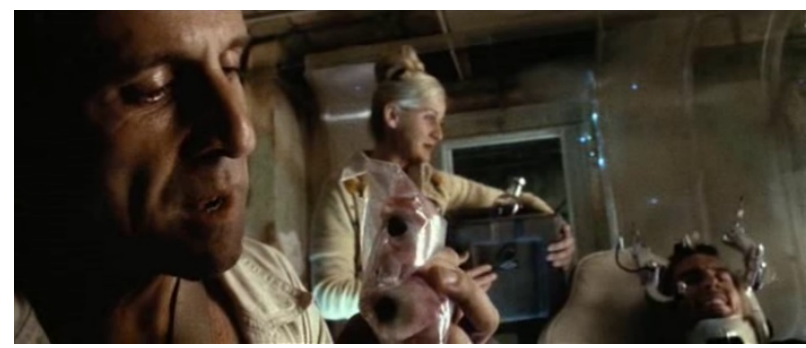

(figura 9)

Um pouco adiante, ainda com os olhos cobertos por faixas após a cirurgia, Anderton tateia uma corda que o leva até o banheiro para se esconder dos policiais que vasculham o prédio. A busca é feita por pequenas esferas de metal que se transformam em aranhas. Estas máquinas caminham rapidamente em busca de fontes de calor e escaneiam os olhos dos habitantes do edifício, invadindo a privacidade de seus apartamentos. Neste trecho a câmera se movimenta mostrando os cômodos de cima, do chamado ponto de vista de Deus, revelando as aranhas que abordam uma mãe e duas crianças, um casal fazendo sexo, outro casal discutindo, um idoso imóvel sentado na privada (10 a 13). A posição em que os moradores são filmados reforça a ideia de um

\footnotetext{
${ }^{19}$ (Clockwork Orange, 1972, Stanley Kubrick) em que Alex está sentado em um cinema com um equipamento que mantém seus olhos abertos obrigando-o a ver cenas de violência e agressão sexual.
} 


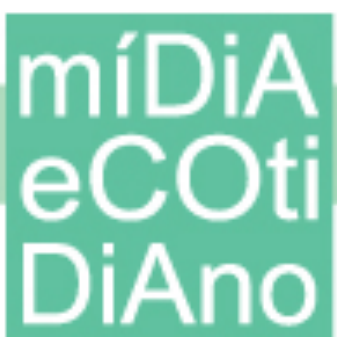

\section{PPGMC} uff

olhar superior do qual nada se pode ocultar. Só que ao invés de um ser divino, é o aparato de vigilância que assume este papel.
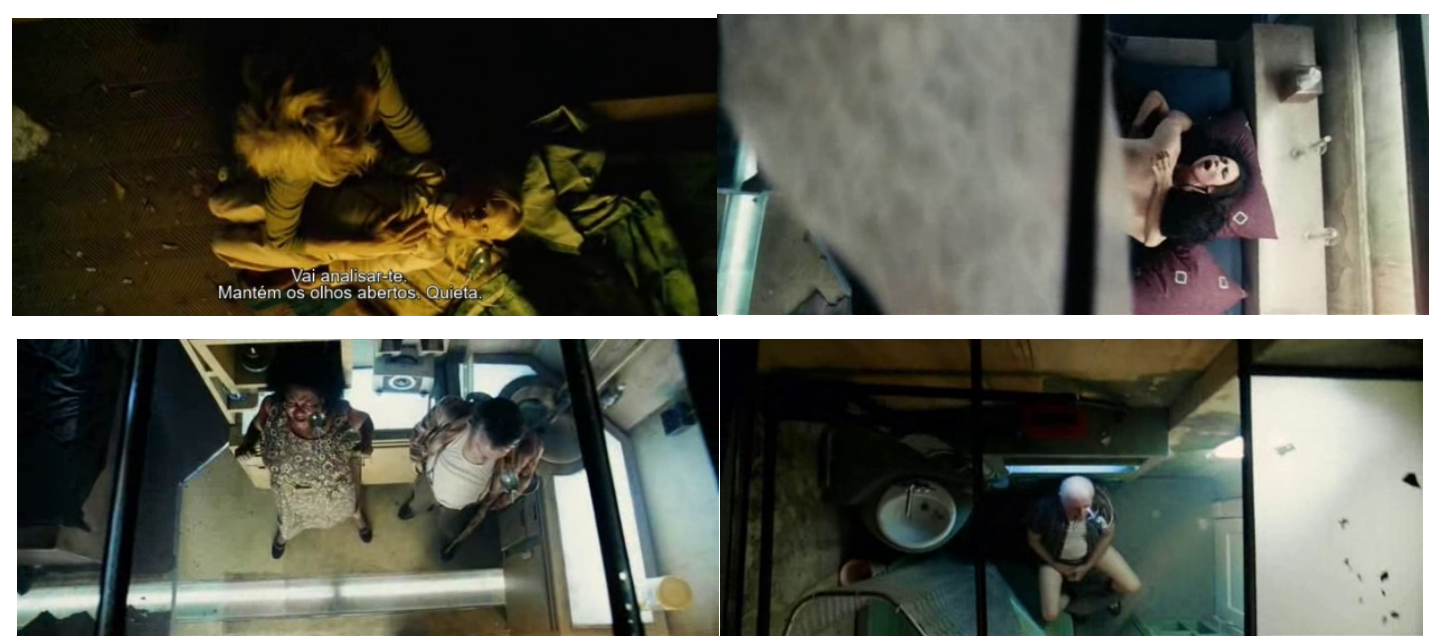

(figuras 10, 11, 12 e 13)

Anderton volta ao Pre Crime para capturar Agatha e esclarecer a presença dele na visão dela. Para entrar ele retira de um saco plástico seus dois globos oculares, removidos na cirurgia, mas os deixa cair no chão. Os olhos rolam no chão até que um deles cai pelos orifícios de uma grade do piso e o outro é pego pela ponta de uma terminação nervosa um segundo antes de cair (figura 14).

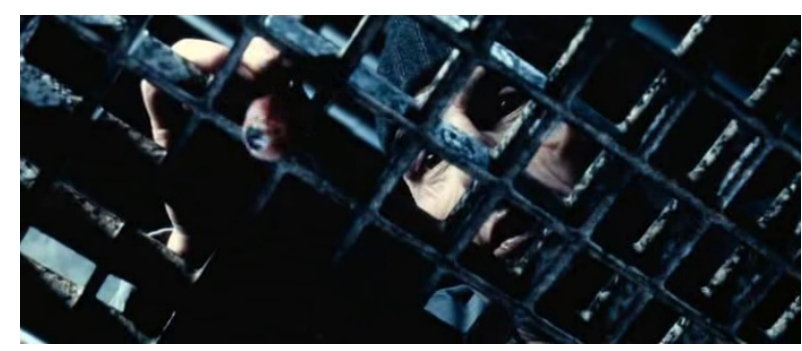

(figura 14)

Ele escapa com Agatha e a leva a um homem que comercializa experiências virtuais em cabines individuais: os clientes pagam, usam óculos especiais e têm visões em três dimensões das fantasias que desejam. Ao escapar dos policiais em um shopping, os enganos do olhar são evidenciados em vários momentos nos quais Agatha pede a Anderton que ambos se posicionem atrás de pessoas e objetos que os impeçam de serem localizados (15). 


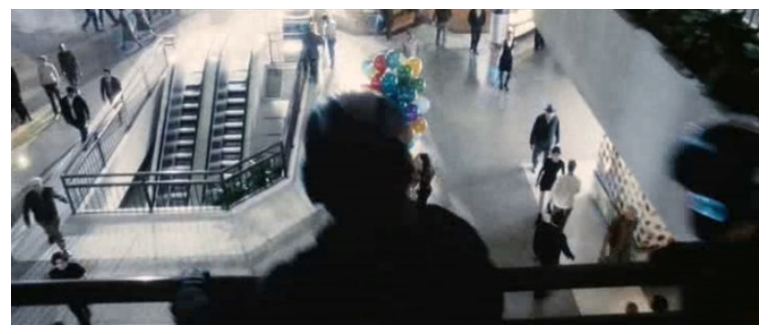

(figura 15)

Como um truque de ilusionismo feito diante do público de um teatro, sem tecnologia algum, a cena soa como um alerta de que os olhos podem ser facilmente enganados por recursos mais primitivos e simples. O recado é que, em um templo do consumo, o shopping, com seus apelos sensoriais às compras - filmado com uma iluminação propositalmente artificial, intensa, criando halos de luz em torno dos atores é possível olhar, mas não necessariamente ver.

Outras duas referências à imagem chamam a atenção. O agente Danny Witwer (Collin Farrel) visita a esposa de Anderton, Lara (Kathryn Morris). Durante o diálogo entre ambos, é possível ver fotografias em preto e branco empilhadas umas sobre as outras. Um pouco adiante, o diálogo prossegue em um laboratório (16) para revelação de fotos a partir de negativos, em claro contraste com a moderna tecnologia de reprodução de imagens mostrada pelo filme.

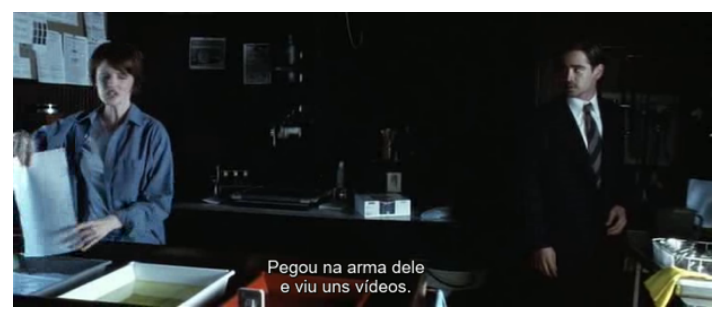

(figura 16)

A pista para esta ênfase na imagem analógica, obtida com filme e ampliada em papel fotográfico, é que ela poderia ser mais confiável que as imagens mentais dos precogs e porque elas também são testemunhas de seres e coisas que existem no mundo real. Em outro momento, Anderton e Samanta entram no quarto de hotel que apareceu nas imagens vistas pela vidente. Sobre a cama do quarto estão dezenas de fotografias de crianças (17). Uma delas é do filho desaparecido de Anderton. Porém, como o hóspede 
do quarto confessa ao ser coagido pelo policial, trata-se de uma armadilha, de um engano despertado pela imagem.

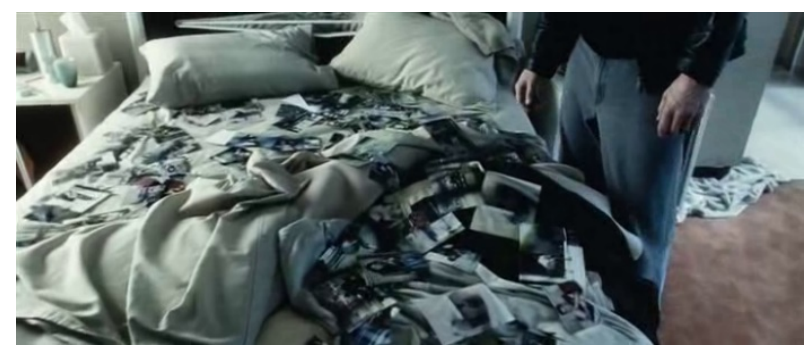

(figura 17)

$\mathrm{O}$ encerramento do filme retoma esta crítica à natureza equivocada da imagem. Com uma narração over informando que o programa foi desativado e os prisioneiros libertados e perdoados, vemos Agatha, Dashiel e Arthur em uma casa, cercados de pilhas de livros (18).

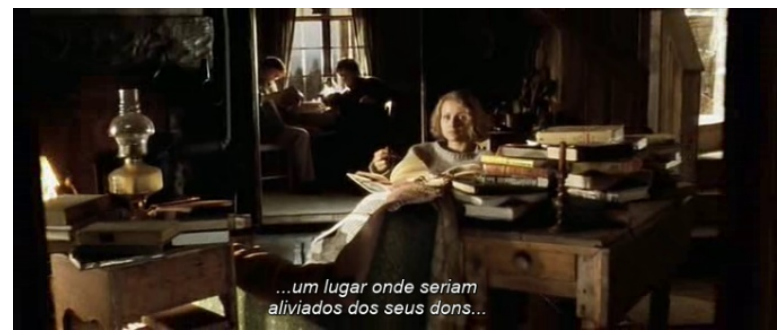

(figura 18)

A medida que a câmera se afasta, vemos que é uma cabana à beira de um lago, com raios alaranjados de sol incidindo sob a água e a copa das árvores. É a palavra escrita e impressa que revela o mundo aos precogs, agora livres. $\mathrm{O}$ conhecimento da experiência que lhes foi negada enquanto eram mantidos sob efeitos de drogas para antecipar crimes agora é fornecido por livros, uma fonte mais confiável que as imagens, enganosas, subjetivas, manipuláveis. Ao invés dos carros que deslizam por prédios, dos cartões que reproduzem imagens tridimensionais de mortos ou dos sensores que empurram todo tipo de produto, impera ao final a calmaria e a beleza de uma paisagem acolhedora, utópica, distante de qualquer aparato tecnológico.

A perspectiva crítica sobre o olhar e o engano das imagens na sociedade contemporânea encontra os códigos do melodrama. $\mathrm{O}$ filme é também uma jornada de re-união de uma família destruída. Ao final, cumprida a missão de destruir o programa Pre Crime, que ajudou a consolidar, Anderton aparece ao lado da esposa, grávida, 
ambos no apartamento dele observando a chuva pela janela. Uma família foi desfeita, outra família será construída. A crítica ao olhar e ao engano da imagem é contrabalanceada com a redenção do personagem e a segunda chance para construir uma unidade familiar. Se Anderton é o pai sem filho, Agatha é a filha sem mãe, livre da escravidão, porém sem a segurança materna.

\section{O horror de ver}

Em Guerra dos Mundos (War of the Worlds), baseado no livro de H. G. Wells, publicado pela primeira vez em 1898, Spielberg lida de forma mais direta com o 11 de setembro, mas também mantém a ênfase no olhar, agora relacionado ao horror de ver. $\mathrm{O}$ livro, publicado em 1898, aborda a invasão de marcianos na Inglaterra vitoriana, o clima de desespero e caos que se instaura e os esforços dos militares para enfrentar a ameaça. Em 1938, Orson Welles criou uma versão radiofônica do enredo, sem alertar os ouvintes americanos que se tratava de uma transmissão dramatizada do livro, o que gerou pânico entre a população e se tornou um dos primeiros casos estudados de paranoia coletiva.

Em 1953, o livro foi novamente adaptado para o cinema, no momento em que imperava o clima anticomunista de caça às Bruxas e o temor de uma invasão soviética nos Estados Unidos, tornando os alienígenas metáforas destes medos. $\mathrm{Na}$ versão de Spielberg, a estrutura do melodrama, como em Minority Report, é mantida e mesclada à ficção científica. Ray Ferrier (Tom Cruise) é um péssimo pai que precisa conquistar o afeto de seus filhos Robbie (Justin Chtawin) e Rachel (Dakota Fanning) ao mesmo tempo que tenta protege-los da invasão alienígena. O 11 de setembro é citado em vários momentos. Após escapar da destruição provocada pelos tripods, Ray se olha diante de um espelho e se vê coberto do que imagina serem cinzas - porém são restos mortais de pessoas dizimadas pelos alienígenas (19). A cena lembra as imagens de pessoas cobertas pelo pó do desabamento das torres em Nova York. 


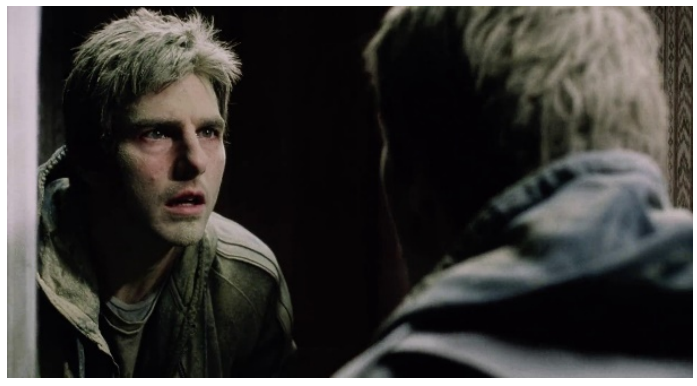

$\left(\right.$ figura 19) ${ }^{20}$

Em fuga por uma autoestrada, os filhos Rachel e Robbie perguntam desesperados ao pai se os agressores "são os terroristas". O clima de caos e pânico fica evidente no embarque da travessia do Rio Hudson por balsa. Uma multidão descontrolada destrói o carro onde Ray e os filhos viajam e arranca os três de dentro. Ray atira para o alto, é ameaçado por um homem com um revólver, seu filho é agredido, o carro é tomado e em seguida bate em um poste.

Quando as naves com os aliens surgem nos céus em várias cidades do planeta, ninguém compreende quem ataca e suas motivações. Esta destruição é mediada pela imagem. O primeiro dos tripods sai de uma rua no centro da cidade e começa a disparar raios que fazem as pessoas desaparecerem (20). Um dos observadores da confusão corre com uma câmera de vídeo nas mãos. A câmera permanece gravando enquanto ele é dizimado pelo raio.

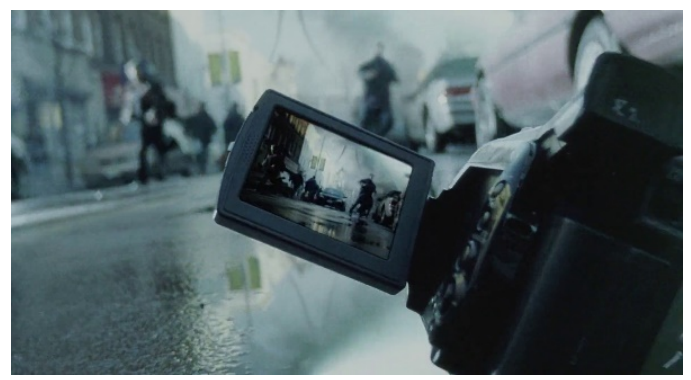

(figura 20)

O diretor nos faz ver o efeito do raio pela tela do visor da câmera caída no asfalto: um homem desaparece totalmente e apenas suas roupas ficam suspensas ao

\footnotetext{
${ }^{20}$ Crédito das imagens: DVD Paramount, 2005, 115'.
} 
vento. Assim como no choque do segundo avião sequestrado contra uma das torres do World Trade Center, a violência dos ataques alienígenas contra a população se materializa com a mediação da imagem - ela é que será a primeira fonte do olhar.

Este horror de ver é concentrado nos planos ponto de vista da personagem Rachel e nos close-ups de suas reações aos acontecimentos, sobretudo os traumáticos. É dela a recusa em ver, por procedimentos de ocultação da realidade por parte de seu pai, e também a paralisia diante do trauma revelado, em um arco dramático da visualidade, que primeiro afasta a criança da cena traumática e ao final a incorpora em sua totalidade, como se tanto ela quanto nós, espectadores, fôssemos sendo preparados para passar da recusa de ver à total revelação do agressor de se sua violência incompreensível.

Após um avião cair sobre a casa da mãe de Robbie e Rachel, Ray ordena que a menina olhe apenas para ele enquanto eles deixam os escombros da casa e passam por corpos e pedaços do avião até alcançarem o carro (21).

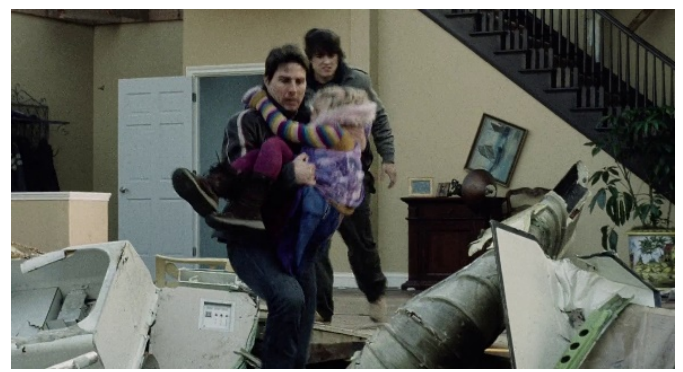

(figura 21)

$\mathrm{Na}$ estrada, à noite, é o olhar dela para o fora de campo que nos revela filas imensas de refugiados caminhado na chuva carregando carrinhos de supermercados com itens pessoais e cartazes com familiares desaparecidos. Na travessia do Hudson, é ela quem percebe a movimentação das aves em direção às árvores quando surgem os tripods e a multidão em pânico corre para entrar na balsa. Mais adiante, ela precisa urinar, Ray para o carro ao lado de um campo e pede que ela permaneça ao alcance dos olhos do pai. Ela se afasta e caminha para encontrar um espaço mais privativo atrás de umas árvores, à beira de um rio, quando surgem dezenas de corpos boiando levados pela correnteza. Ela se assusta e logo atrás dela aparece o pai e fecha seus olhos (22 a 24). 

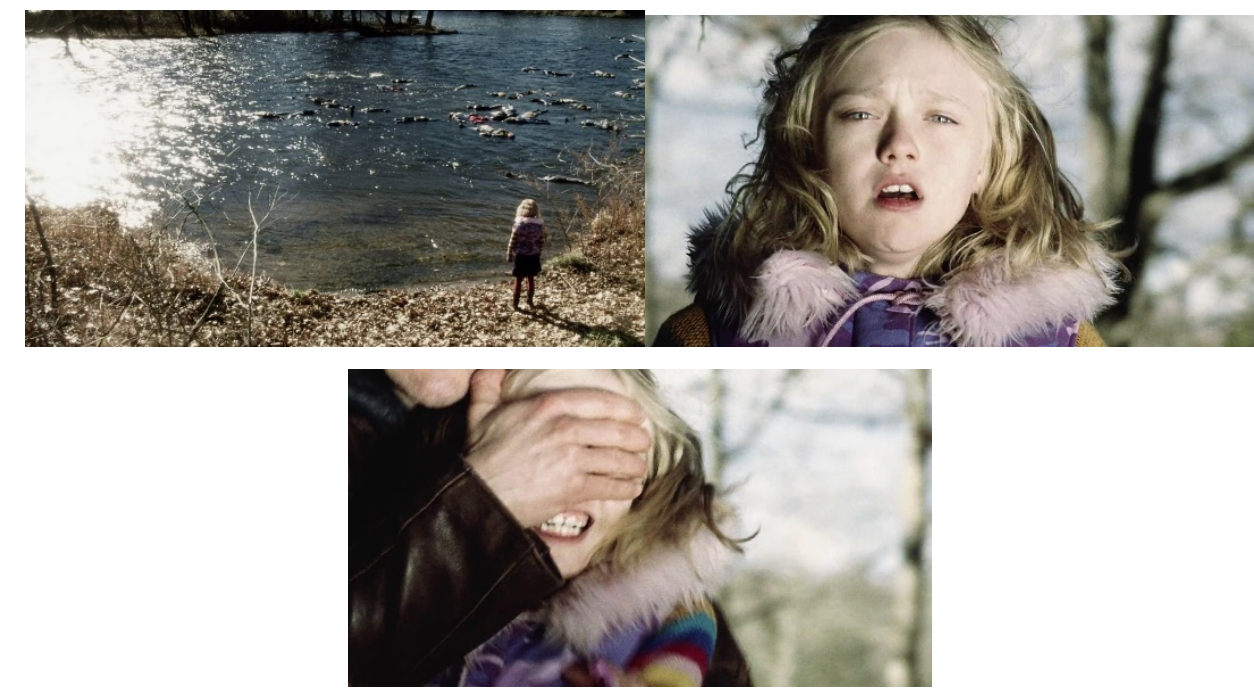

(figuras 22, 23 e 24)

Quando Ray e Rachel se escondem no porão escuro e sujo da casa de Harlan Ogilvy (Tim Robbins) o jogo de ver e impedir a visão se torna mais evidente. Um grande tentáculo móvel com um enorme olho na ponta vasculha cada cômodo do porão. A cada movimento do tentáculo, Ray, Rachel e Harlan caminham silenciosamente para se esconder do mecanismo. Até que os três precisam ficar encolhidos atrás de um espelho, cuja superfície revela o reflexo do grande olho (25). Os passos atrás do mecanismo e a ocultação na face oposta do espelho, objeto presente nos filmes de Spielberg, revelam que o olhar, por mais avançado e atento, pode ser enganado.

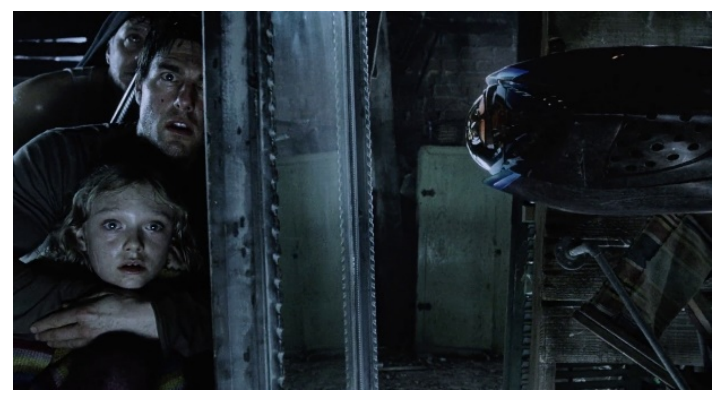

(figura 25)

Rachel observa ondas de água se movendo no piso, anunciando a entrada de quatro seres alienígenas, cujas cabeças pontiagudas e pernas compridas e finas são mostrados por Spielberg em sombras projetadas na parede do porão. Um plano mostra Rachel assustada, sentada em uma poltrona, como um espectador preso a um filme de 


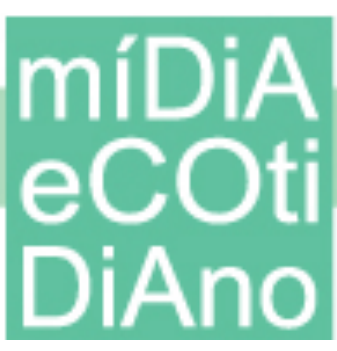

\section{PPGMC}

horror. Atrás dela, vemos entre o espaço de uma ripa de madeira, a passagem de um destes seres (26).

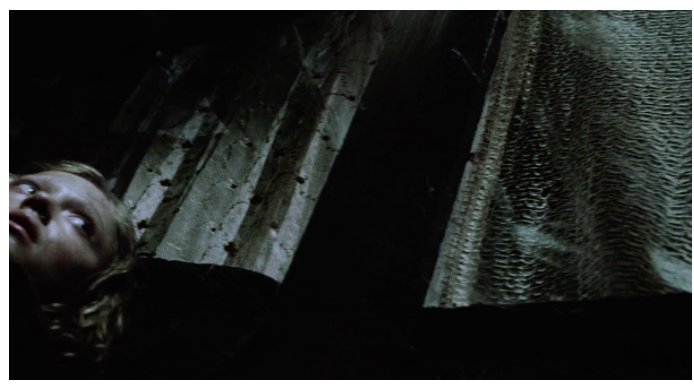

(figura 26)

Um deles inclina o corpo adiante, movendo a poltrona onde está Rachel. Vemos em detalhes sua face triangular com grandes olhos. Ela segura a respiração, com os olhos arregalados de pavor. A poltrona volta à posição anterior e ela observa os dois seres tocando nas rodas de uma bicicleta - momento em que dois pedaços de madeira formam um segundo enquadramento para seus olhos assustados (27 e 28).

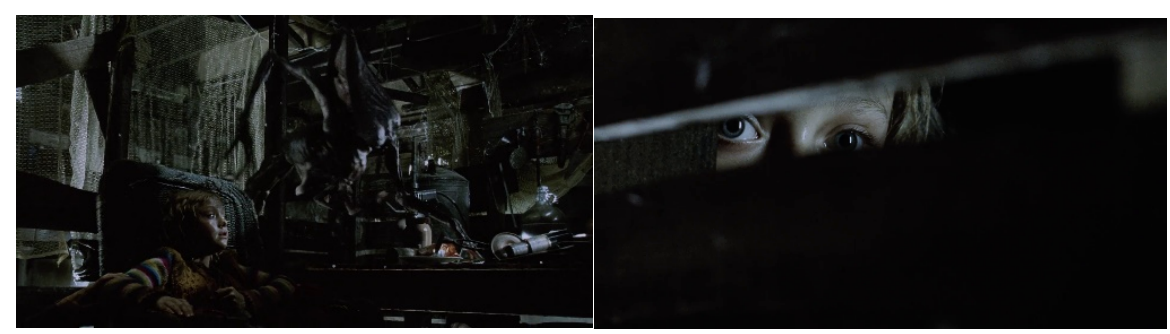

(figuras 27 e 28)

Mais adiante, Ray venda os olhos de Rachel e pede que, independente do que ela ouvir, não os abra de jeito algum (29). Pede ainda que ela cante Hushabye Mountain, do filme O Calhambeque Magico (Chitty Chitty Bang Bang, Ken Hughes, 1968).

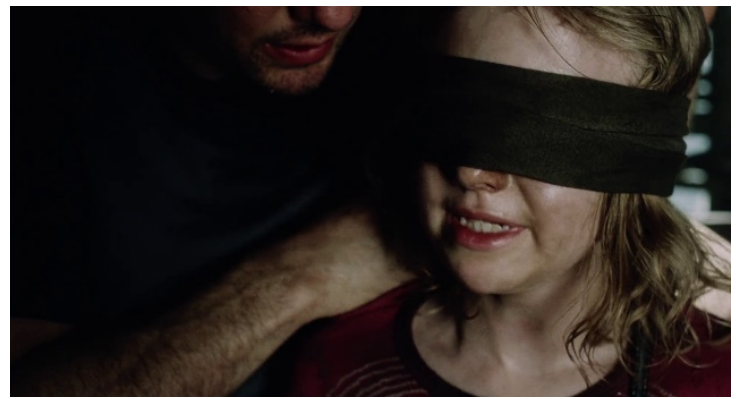

(figura 29)

Ray entra no cômodo pequeno onde Harlan, visivelmente alterado, grita e cava um buraco para escapar. Ouvimos gritos. Rachel termina de cantar a música, Ray sai do 
cômodo com sangue no rosto, os dois se abraçam na escada. Em seguida, pai e filha dormem no sofá. Rachel ouve um barulho, acorda, senta-se e diante dela está o grande olho do tentáculo, tão grande que vemos o reflexo (30) da menina em sua esfera de vidro espelhado.

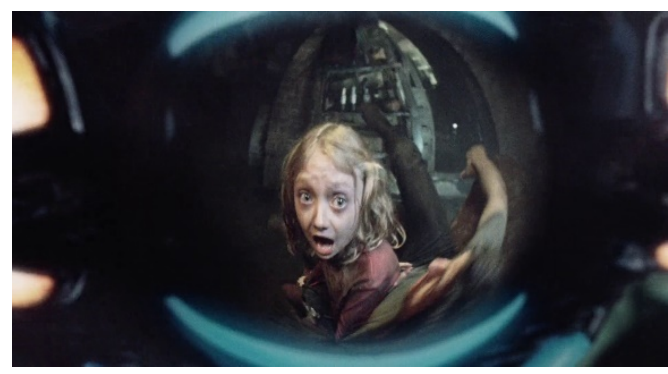

(figura 30)

Diante do que não mais pode ser evitado para seus olhos, ela reage gritando. $\mathrm{O}$ pai acorda, empurra o tentáculo e o destrói a golpes de machado - o olho que ameaça e destrói deve ser apartado de seu agressor. Rachel corre, Ray a procura na paisagem rural avermelhada de sangue e de restos humanos. Ray é capturado para dentro de uma estrutura em forma de rede de um dos tripods, onde encontra Rachel, com os olhos abertos, em choque, em silêncio, enquanto outros prisioneiros gritam e choram a sua volta.

Se Minority Report critica a imagem como enganosa e duvida do que os olhos apresentam ao ser humano - em uma referência direta à violência das imagens dos atentados e ao choque sobre os espectadores - em Guerra dos Mundos, produzido já no clima nacionalista a favor da guerra contra Afeganistão e Iraque, a referência aos atentados é mais direta. Mas o diretor faz questão de continuar refletindo sobre o olhar, o horror de ver e a experiência traumática, desta vez sendo processada pelos olhos de uma criança. Enquanto a discussão na mídia era concentrada na pauta militar, histórica, geopolítica, religiosa e em outras vertentes, Spielberg criou dois filmes que apresentavam propostas alternativas para lidar com os conflitos daquele momento, em filmes de gêneros consagrados, de apelo afetivo e popular, em um entretenimento comprometido com seu tempo. 
Referências

BORDWELL, David. THOMPSON, Kristin. Film History - an introduction. McGraw Hill Higher Education. Columbus: 2002.

COUSINS, Mark. História do Cinema -Dos clássicos mudos ao cinema moderno. Martins Fontes. São Paulo: 2013.

EASY RIDERS. O cinema da Nova Hollywood. Catálogo da Mostra. Centro Cultural Banco do Brasil. Rio de Janeiro, 2015.

FRIEDMAN, Lester. Citizen Spielberg. University of Illinois Press, Chicago: 2006.

EDGERTON, Gary. HART, William, HASSENCAH, Frances. Televising $9 / 11$ and Its Aftermath: The Framing of George W. Bush's Faith-Based Politics of Good and Evil. In: NORDEN Martin (edit.). The Changing Face of Evil in Film and Television. Rodopi B.V., Amsterdam - Nova York, 2007.

MC BRIDE, Jim. Steven Spielberg - a biography. University Press of Mississipi. Jackson: 2011.

WASSEL, Frederick. Steven Spielberg's America. Polity Press. Cambridge: 2010.

WESTWELL. Guy. Parallel Lines - Post-9/11 American Cinema. Wallflower Press Book, Nova York, 2014. 